УДК: 78.01"19/20"

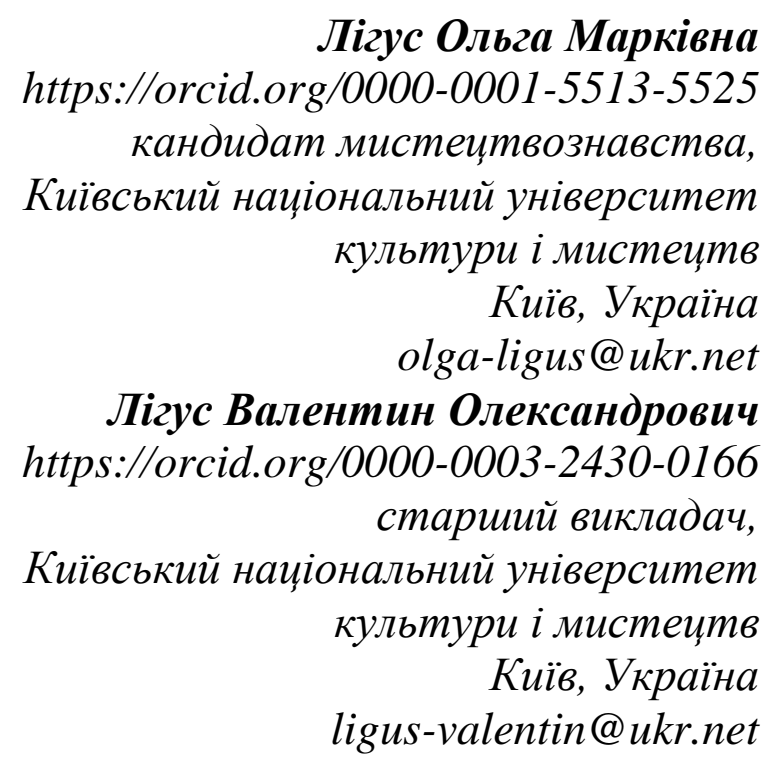

\title{
ПРОБЛЕМА ЖАНРУ В МУЗИКОЗНАВЧИХ ДОСЛІДЖЕННЯХ XX-XXI СТ.
}

Мета роботи. Стаття присвячена історіографії проблеми музичного жанру - однієї з найважливіших категорій музичного мислення, вивчення якої вирізняється дискусійним характером. Розглядаються різні трактування поняття жанру в дослідженнях XX-XXI ст. В основі методології - теоретичний метод систематизації, що полягає в осмисленні наукових концепцій жанру. Використано ін. теоретичні методи: абстрагування (у виділенні найістотніших рис жанру), аналіз (у встановленні зв'язків між смисловими рівнями i характеристиками категорії жанру) та синтез (у розгляді жанру як компонента ієрархічної системи музики). Також застосовано історичний метод (у розгляді історичної типології жанру). Наукова новизна полягає в систематизації музикознавчого досвіду дослідження поняття жанру, в окресленні сучасних тенденцій вивчення жанрової проблематики, у розвитку теоретичного дискурсу жанрової природи музичних явищ. Висновки. На підставі опрацювання наукових досліджень XX-XXI ст. визначено базові положення теорії жанру; систематизовано наукові концепції жанру; виокремлено концепцію «жанрового віку» М. Арановського як дієвий методологічний інструмент у дослідженні жанрової природи музики XX-XXI ст.

Ключові слова: музичний жанр, теорія жанру, функції жанру, ознаки жанру, типологія жанрів.

Лигус Ольга Марковна, кандидат искусствоведения, Киевский национальный университет культуры и искусств, Киев, Украина

Лигус Валентин Александрович, старший преподаватель, Киевский национальный университет культуры и искусств, Киев, Украина

Проблема жанра в музыковедческих исследованиях XX-XXI века 
Цель работы. Статья посвящена историографии проблемы музыкального жанра - одной из наиболее важных категорий музыкального мышления, изучение которой отличается дискуссионным характером. Рассматриваются различные трактовки понятия жанра в исследованиях XX-XXI века. В основе методологии - теоретический метод систематизации, который состоит в осмыслении научных концепций жанра. Использованы другие теоретические методы: абстрагирования (при выделении наиболее существенных черт жанра), анализ (при установлении связей между смысловыми уровнями и характеристиками категории жанра) и синтез (при рассмотрении жанра как компонента иерархической системы музыки). Также применен исторический метод (при рассмотрении исторической типологии жанра). Научная новизна состоит в систематизации музыковедческого опыта исследования жанра, в обозначении современных тенденций изучения жанровой проблематики, в развитии теоретического дискурса жанровой природы музыкальных явлений. Выводы. На основе обработки научных исследований XX-XXI в. определены базовые положения теории жанра; систематизированы научные концепции жанра; выделена концепция «жанрового возраста» М. Арановского как действенный методологический инструмент в исследовании жанровой природы музыки XX-XXI в.

Ключевые слова: музыкальный жанр, теория жанра, функции жанра, черты жанра, типология жанров.

Lihus Olha, PhD in Art Criticism, Kyiv National University of Culture and Arts, Kyiv, Ukraine

Lihus Valentyn, Senior Lecturer, Kyiv National University of Culture and Arts, Kyiv, Ukraine

The problem of Genre in the musicological research of the 20th 21st centuries

The purpose of the article. The article is dedicated to the historiography of the musical genre problem - one of the most significant categories of the musical reasoning, the examination of which has a controversial nature. Different interpretations of the notion of genre in the research of the $20^{\text {th }}-21^{\text {st }}$ centuries are analyzed. The foundation of the methodology is a theoretical method of systematization, which presupposes the consideration of the scientific conceptions of genre. Other methods are also used: abstraction (to define the essential features of genre), analysis (to make connections between levels of meaning and characteristics of genre as a category), and synthesis (to perceive genre as a component of hierarchic system of music). Moreover, the historical method is applied to consider the historical typology of genre. Scientific novelty presupposes systematization of musicological experience of research of genre as a notion, definition of the contemporary tendencies of examination of genre problematic, development of theoretical discourse of genre essence of musical phenomena. Conclusion. Based on the elaboration of the research of the $20^{\text {th }}-21^{\text {st }}$ centuries the fundamental principles of the genre theory are defined; scientific conceptions of genre are systematized; conception of the "genre age" of M. Aranovskyi as an influential methodological 
instrument in the investigation of genre essence of music of the $20^{\text {th }}-21^{\text {st }}$ centuries is defined.

Key words: musical genre, genre theory, genre functions, genre features, genre typology.

Вступ. «Музика завжди є чимось більшим за жанр, але без жанру немає музики» [6, с. 438]. Це зауваження сучасного музикознавця Г. Данузера переконує, що пізнання будь-якого музичного явища неможливе без вивчення його жанрової специфіки. Означене завдання, насамперед, виявляє цілу низку труднощів, пов'язаних із відсутністю чітких меж дефініції жанру. Особливо гостро ця проблема постає перед дослідниками музичного мистецтва XXI ст., яке характеризується жанровим синтезом, обумовленим естетикою епохи постмодерну.

Теорія музичного жанру XX-XXI ст. представлена фундаментальними працями вчених різних поколінь: Г. Бесселера [12], В. Цуккермана [10], А. Сохора [8], С. Назайкінського [5], М. Арановського [1], О. Соколова [7], М. Кагана [3], Л. Березовчук [2], Л. Шаповалової [11]. Майже всі дослідники проблеми жанру ставили за мету створити універсальну систему жанрової ієрархії, намагаючись визначити сталі параметри жанру та виділити серед них основний. Однак усі спроби вивести формулу жанру, яка би «працювала» в різних умовах, привели до виникнення різних наукових концепцій, які взаємодоповнюють одна одну. Як слушно відзначив М. Каган: «різні тлумачення змісту цього поняття позначають здатність художньої творчості модифікуватися на різних рівнях і в різних площинах багатовимірної структури мистецтва. Тому жанри вирізняються і за відмінностями предметів та способів художнього пізнання, і за характером виражених у мистецтві духовних станів, i за типом створених образних моделей, i за особливостями вибудованих у творах формальних конструкцій, і врешті, за специфікою їх знакових систем» $[3$, c. 111$]$.

Таким чином, відсутність чітких меж поняття жанру та необхідність сучасного осмислення цієї категорії актуалізує історіографічний аспект жанрової проблематики.

Мета статті - висвітлити і систематизувати різні концепції музичного жанру, зумовлені відмінністю наукових підходів.

Виклад основного матеріалу. Теорію жанру, представлену в означених працях, характеризує цілий спектр різноманітних трактувань жанру з погляду змістовності, поліфункціональності, художньої типізації та системної цілісності. Загалом комплекс категоріальних ознак жанру визначається трьома провідними чинниками:

1) соціокультурним, пов'язаним із соціальним призначенням жанру;

2) комунікативним, який вказує на умови й функції його побутування;

3) іманентно-музичним, яким охоплено особливості складу та способу виконання, змісту, форми й засобів виразності.

Певний чинник дослідники обирали за основний критерій жанру, внаслідок чого сформувалося три основних напрями жанрової класифікації: 
соціомузичний (Г. Бесселер [12] та А. Сохор [8]), змістовий (В. Цуккерман [10]) та функціональний (О. Соколов [7]).

Г. Бесселер виділив критерій зв'язку музики з побутом, внаслідок чого розподілив жанри на дві категорії. До першої належать «ужиткові», прикладні жанри, а до другої - ті, що «подаються» слухачеві як художньо-естетичні об’єкти. Співзвучним цій теорії є дослідження А. Сохора, який розподілив жанри на чотири групи, беручи до уваги особливості обстановки та умов виконання музики. Перша (культові й обрядові жанри) та друга (масовопобутові) групи відповідають «ужитковим» жанрам Г. Бесселера, а третя (концертні жанри) і четверта (музика, що звучить у театрі) - першій жанровій категорії німецького музикознавця (жанри, що «подаються»).

В. Цуккерман розрізняв жанри первинні (пов’язані з первісними умовами побутування) та вторинні (жанри професійної творчості), однак визначальним параметром жанру в його концепції обрано зміст, адже, на думку вченого, «змістова сторона - найважливіша та найглибша серед усіх» [10, с. 61-62]. Виходячи з цього, В. Цуккерман диференціював жанри на три категорії:

а) ліричні;

б) оповідні та епічні;

в) жанри, пов'язані з процесом руху.

Відмінною від попередніх є жанрова систематика О. Соколова, для якого на перший план виходить зв'язок музики 3 ін. видами мистецтва або позамузичними компонентами, а також, іiі функції- практичні та художні [10, с. 23]. У такий спосіб дослідник розподіляє жанри на чотири групи:

1) чиста музика, до якої належать безпрограмні музичні твори;

2) музика, що взаємодіє з ін. видами мистецтва;

3) прикладна музика, пов'язана з ужитком у побуті;

4) прикладна музика, яка пов’язана як із побутом, так i 3 ін. видами мистецтва.

У всіх дослідженнях категорія музичного жанру осмислюється багатовимірно: як ієрархічна система складових елементів, які взаємодіють, та, водночас, як елемент системи вищої організації. Зокрема, М. Арановський розглядав жанр як «екстрамузичне» явище, яке знаходиться на перетині музичного та «позамузичного». Учений виділив у жанровій системі дві структури: зовнішню та внутрішню. Зовнішня, на його думку, співвідноситься iз комунікативною функцією і виражає онтологічну сутність жанру, а внутрішня - «структурно-семантичний інваріант» - визначає його гносеологічний зміст. Характер взаємодії обох структур М. Арановський описав так: «Жанр сполучається з навколишнім середовищем через свою зовнішню структуру, яка, насамперед, може зазнавати впливу цього середовища та передавати його внутрішній структурі» [1, с. 38].

Визначення «структурно-семантичний інваріант» М. Арановський розшифровує як «тип змісту, який міститься в типі структури» [1, с. 32], що відображає сутність жанру як «кінцевого пункту типізації». У цьому сенсі дослідник розвиває ідею «узагальнення через жанр», висунуту ще в 30-ті роки 
ХХ ст. А. Альшвангом, а також концепцію В. Цуккермана, який, також, трактував жанр як «типізований зміст» [10].

Якість жанру «типізувати» відзначила і Л. Шаповалова, на думку якої типізація є його основною естетичною функцією [11, с. 69]. Спираючись на теоретичні положення О.Соколова, дослідниця розглянула способи функціонування жанру в чотирьох вимірах, у яких він постає як: тип інтонування, тип композиції, тип драматургії та тип співвідношення художніх видів. Внаслідок цього Л. Шаповалова дійшла висновку, що становлення і розвиток жанрової типізації відбувається на інтонаційному рівні та вивела поняття «жанровості», яке означає «типізовану інтонацію, здатність до узагальнення музичної образності» [11, с. 73].

Розуміння категорії жанру як системи функцій постає в дослідженнях Л. Березовчук, яка виділила три основні функції жанру - комунікативну, нормативну та аксіологічну, які «забезпечують музичну комунікацію і передачу соціального досвіду за допомогою різнорівневих кліше знакового типу» [2, с. 109]. Є. Назайкінський поставив під сумнів правочинність концепції Л. Березовчук, в якій, на його думку, наявні суттєві невідповідності стосовно історії проблеми та принципу систематики функцій. Насамперед, вчений виділив три основні жанрові функції: комунікативну, тектонічну та семантичну [5, с. 95].

Характерна для сучасної науки тенденція підвищення історизму мислення, зумовлена прагненням пізнати художнє явище в його еволюції в культурному просторі, актуалізує історичні аспекти жанру. Зважаючи на історичну рухливість цієї категорії, що в часі «переживає» різні етапи буття: народження, розвитку, вгасання та відродження (в окремих випадках), а також, на універсальну здатність жанру до «узагальнення», єднаючи різні епохи, на перший план виходять питання історичної типології жанрів та жанрової еволюції. У різний час ці питання висвітлювали В. Конен [4], М. Арановський [1], Є. Назайкінський [5], М. Каган [3], К. Зенкін, В. Суханцева [9], М. Черкашина.

3 погляду історичної типології жанрів простежується еволюція музикознавчої думки від ідеї дихотомії жанрових груп, яку брали за основу Г. Беселер («ужиткові жанри - жанри, які подаються») та В. Цуккерман («первинні - вторинні»), - до розподілу жанрів на три категорії: «народні професійні - “третій шар”», запропонованого В. Конен, де під «третім шаром» дослідниця розуміє джаз і рок-музику, беручи до уваги соціомузичний контекст ХХ ст. [4]. Розвиваючи ідею жанрової класифікації В. Конен, М. Каган відносить до «третього шару» також музику для радіо, телебачення та кінематографа [67, с. 117].

Принципом «тріади» в побудові жанрової типології керувався i Є. Назайкінський, який класифікував жанри згідно 3 «трьома соціально значущими формами буття музики», які в історичному часі послідовно нашаровувалися одна на одну [5, с. 117-118]. Основним критерієм для виявлення специфіки цих форм було їхнє відношення до технічного прогресу. Так, для першої, найдавнішої форми, яку дослідник назвав «синкретичною», 
характерні «синхронізм творення, втілення та сприйняття» [5, с. 120], для другої, форми професійної творчості, - на першому плані постала естетична функція жанру, а в умовах третьої, «віртуальної» форми, що пов’язана з електроакустичною реалізацією музики, жанри постають «автономними номінальними об'єктами», відірваними від єдності часу й простору в процесі виконання та сприйняття музики [5, с. 129].

Аналізуючи особливості трьох форм буття музики, Є. Назайкінський приходить до висновку, що традиційні музикознавчі визначення жанру стосуються саме другої форми, яка відповідає другим жанровим групам у типологіях Г. Бесселера, В. Цуккермана та В. Конен. Водночас учений констатував, що в межах другої форми можуть народжуватися і «первинні» для даних умов жанри, такі як «пори року», «багатель», «сторінка 3 альбому», «експромт».

Останнє зауваження стосується ін. ключового аспекту - історичної поетики професійної творчості, який розкриває неоднорідність процесу жанрової еволюції в синхронічному зрізі. Ця неоднорідність полягає в тому, що, одні жанри на певному історичному відрізку переживають своє становлення, ін. - накопичують нові ознаки, деякі трансформуються в інші жанрові утворення, а решта- відходять у забуття. Таким чином, стає очевидним феномен жанрового «віку», який регулюється характером історичних змін, соціокультурними та індивідуально-художніми впливами.

У зв’язку з цим М. Арановський розрізняє три основні стадії розвитку жанру: формування, стабілізацію та дестабілізацію, розглядаючи еволюцію жанру симфонії в ХX ст. [1, с. 5]. Відправним пунктом концепції вченого було виведене ним поняття семантичного інваріанту, тобто жанрового канону, відносно якого відбуваються «вікові» зміни жанру. Виходячи 3 цього, дослідник виявляє наріжний вектор жанрового розвитку: від одиничних жанрових втілень (стадія формування) - до набуття жанром «типізованого шару», а згодом семантичного інваріанту (жанрова стабілізація) - зрештою, знову до рівня індивідуалізації, що супроводжується поступовою руйнацією семантичного інваріанту та подальшою відмовою від типізованого шару (стадія дестабілізації жанру).

Наукова новизна полягає в систематизації музикознавчого досвіду дослідження поняття жанру, в окресленні сучасних тенденцій вивчення жанрової проблематики, у розвитку теоретичного дискурсу жанрової природи музичних явищ.

Висновки. Необхідність класифікації та систематизації проблем жанру виникла внаслідок неоднозначності трактування цього багатогранного поняття, яке охоплює аспекти генезису, морфології, функцій, стилістики та історичної типології. Наукові розбіжності навколо жанру простежуються на різних етапах його дослідження в теоретичному, історичному, системно-структурному й типологічному ракурсах.

На підставі розгляду досліджень Г. Бесселера, В. Цуккермана, А. Сохора, Є. Назайкінського, М. Арановського, О. Соколова, М. Бонфельда, Л. Березовчук, Л. Шаповалової систематизовано теоретичні концепції жанру 3 позицій 
змістовності, поліфункціональності, художньої типізації та системної цілісності. Також сформульовано три основні чинники, якими визначається комплекс його категоріальних ознак (соціокультурний, комунікативний, іманентно-музичний) та виділено три основні напрями жанрової класифікації, викладені в теоріях Г. Бесселера і А. Сохора; В. Цуккермана; О. Соколова.

Аналіз праць, присвячених історичним аспектам проблеми жанру (історичній типології та історичній поетиці жанрів) виявив неоднорідність процесу еволюції жанрів у синхронічному зрізі, що згідно 3 концепцією М. Арановського, актуалізує жанрового «віку», визначивши три основні стадії розвитку жанру: формування, стабілізацію та дестабілізацію. Дієвість цієї концепції особливо актуальна 3 погляду на музичне мистецтво сучасної інформаційної епохи, якому властива руйнація традиційних жанрових моделей, так само як і виникнення жанрових гібридів.

\section{Список використаних джерел}

1. Арановский М. Г. Структура музыкального жанра и современная ситуация в музыке / М. Г. Арановский // Музыкальный современник. - Москва : Сов. композитор, 1987. - Вып. 6. - С. 5-44.

2. Березовчук Л. Н. Музыкальный жанр как система функций (психологические и семиотические аспекты) / Л. Н. Березовчук // Аспекты теоретического музыкознания. (Проблемы музыкознания). - Ленинград, 1989. Вип. 2. - С. 95-122.

3. Каган М. С. Музыка в мире искусств./ М. С. Каган. - СанктПетербург : «Ut», 1996. - 232 с.

4. Конен В. Дж. Третий пласт. Новые массовые жанры в музыке XX века / В. Дж. Конен. - Москва : Музыка, 1994. - 160 с.

5. Назайкинский Е. В. Стиль и жанр в музыке : учеб. пособие для студ. высш. учеб, заведений / Е. В. Назайкинский. - Москва : Гуманит. изд. центр Владос, 2003.- 248 с.

6. Новак А. Еволюція музичних жанрів у ХХ ст. в когнітивній інтерпретації. Поняття музичного жанру - проблеми сучасної методології та художньої практики. - / А. Новак // Українське музикознавство. - Київ, 2004. Вип. 33. - С. 438-447.

7. Соколов О. В. Морфологическая система музыки и ее художественные жанры : монографія / О. В.Соколов. - Нижний Новгород : Изд-во ННГУ, 1994. $220 \mathrm{c}$.

8. Coхор А. Н. Теория музыкальных жанров: задачи и перспективы / А. Н. Сохор // Теоретические проблемы музыкальных форм и жанров. Москва : Музыка, 1971. - С. 292-310.

9. Суханцева В. К. Музыка как мир человека. От идеи вселенной к философии музыки / В. К. Суханцева - Київ : Факт, 2000. - 176 с.

10. Цуккерман В. А. Музыкальные жанры и основы музыкальных форм / В. А. Цуккерман. - Москва : Музыка, 1964. - 159 с. 
11.Шаповалова Л. В. О взаимодействии внутренней и внешней формы в исторической эволюции музыкальной жанровости : дис. канд. искусствоведения : спец. 17.00.02 - Музыкальное искусство / Шаповалова Людмила Владимировна ; Киевская гос. консерв. им. П. И. Чайковского. - Киев, 1986. - 172 с.

12. Besseler H. Das musikaliche Hören der Neuzeit / H. Besseler. - Berlin, Academie-Verlag, 1959. - S. 12-14.

\section{References}

1. Aranovskij, M.G. (1987). 'Structure of musical genre and modern situation in music'. Muzykal'nyj sovremennik [Musical Contemporary], no 6, pp.5-44.

2. Berezovchuk, L.N. (1989). 'Musical genre as a system of functions (psychological and semiotic aspects)'. Aspekty teoreticheskogo muzykoznaniya. Problemy muzykoznaniya [Aspects of theoretical musicology. Problems of musicology]. no 2, pp. 95-122.

3. Kagan, M.S. (1996). Music in the world of Arts. Sankt-Peterburg: "Ut".

4. Konen, V.Dzh. (1994). The Third Layer. New mass genres of Music of the $20^{\text {th }}$ century. Moskva: Muzyka.

5. Nazajkinskij, E.V. (2003). Style and Genre in Music: Study guide for college university students. Moskva: Academic publishing center Vlados.

6. Novak, A. (2004). 'Evolution of musical genres of the $20^{\text {th }}$ century in the cognitive interpretation. The notion of musical genre - a problem of modern methodology and artistic practice'. Ukrainske muzykoznavstvo [Ukrainian Musicology], no 33, pp.438-447.

7. Sokolov, O.V. (1994). Morphologic system of Music and its artistic Genres: monograph. Nizhniy Novgorod: Publishing house of Nizhniy Novgorod State University.

8. Sohor, A.N. (1971). 'Theory of Musical Genres: Challenges and Prospects'. Teoreticheskie problemy muzykal'nyh form $i$ zhanrov [Theoretical Problems of Musical Forms and Genres], pp. 292-310.

9. Suhanceva, V.K. (2000). Music as a World of Human. From the Idea of the Universe to the Philosophy of Music. Kiev: Fakt.

10. Tsukkerman, V.A. (1964). Musical Genres and foundations of Musical Forms. Moskva: Muzyka.

11. Shapovalova, L.V. (1986). To the interaction of internal and external form of historical evolution of music genre. D.Ed. Kiev State Conservatory named after P.I.Chaykovskiy.

12. Besseler, H. (1959). Das musikaliche Hören der Neuzeit. Berlin: AcademieVerlag.
(C) Лizyc O. M, 2018
(C) Лizyc B. O., 2018 